Pustaka Karya: Jurnal Ilmiah Ilmu Perpustakaan dan Informasi Vol. 8 No. 1, Juni 2020, Hal. 25-32

http://dx.doi.org/10.18592/pk.v7i15.3757

ISSN (p) : 2089-5216 | ISSN (e) : 2723-7699

\title{
Pemanfaatan buku oleh mahasiswa sebagai penunjang aktivitas akademik di era generasi milenial \\ ${ }^{1}$ Arin Prajawinanti
}

${ }^{1}$ Program Studi Ilmu Perpustakaan dan Informasi Islam UIN Tulungagung

${ }^{1}$ Jl. Mayor Sujadi No.46, Kudusan, Plosokandang, Kec. Kedungwaru, Kabupaten Tulungagung, Jawa Timur 66221

Email: ${ }^{1}$ prajainan@gmail.com

\begin{abstract}
Students are intellectual candidates for the future generation of the nation. Students must be able to run as creators of change. They need sources of information to support all their academic activities. In this era it is available in various forms, especially supported by the current increase in information. The selection of information sources made by students is carried out with various rational considerations and also the motivations possessed by students to achieve goals. The existence of external encouragement such as support from lecturers or the surrounding environment also has an important role in influencing the choice of information sources used. In millennial generation, students choose to use books to support many academic activities. Apart from books, students also take advantage of information sources from journals.
\end{abstract}

Keywords: motivation; rational choice; use of books

\begin{abstract}
ABSTRAK
Mahasiswa merupakan calon intelektual masa depan generasi bangsa. Mahasiswa harus bisa menjalankan perannya sebagai pencipta perubahan. Mereka membutuhkan sumber informasi untuk menunjang seluruh aktivitas akademiknya. Di era sekarang ini sumber informasi tersedia dalam berbagai bentuk, apalagi didorong dengan adanya ledakan informasi saat ini. Pemilihan sumber informasi yang dilakukan oleh mahasiswadilakukan dengan adanya berbagai pertimbangan rasional dan juga motivasi yang dimiliki oleh mahasiswa untuk mencapai tujuan. Adanya dorongan dari luar seperti dukungan dari dosen atau lingkungan sekitar juga memiliki peran penting dalam mempengaruhi pilihan sumber informasi yang digunakan. Di lingkungan generasi milenial saat ini masih banyak mahasiswa yang memilih memanfaatkan buku untuk menunjang aktivitas akademiknya. Selain buku mahasiswa juga memanfaatkan sumber informasi dari jurnal.
\end{abstract}

Kata Kunci: motivasi; pemanfaatan buku; pilihan rasional

\section{PENDAHULUAN}

Mahasiswa adalah bagian dari kelompok masyarakat dimana mereka mendapatkan status akademik dikarenakan terikat dengan suatu perguruan tinggi. Dalam suatu lapisan masyarakat mahasiswa memiliki predikat sebagai calon intelektual atau cendekiawan muda. Pada Peraturan Pemerintak Republik Indonesia No.30 tahun 1990 didefinisikan bahwa mahasiswa adalah peserta didik yang secara administrasi terdaftar dan belajar di suatu perguruan tinggi tertentu. Mahasiswa memiliki peran untuk menciptakan dan melahirkan suatu perubahan (creator of change). Mahasiswa sebagai calon intektual akan menjadi aktor yang dapat merubah masa depan suatu 
bangsa. Seperti yang diungkapkan Tamrin bahwa menurutnya sebagai mahasiswa, tugas utama mereka adalah belajar (Tribun Pekanbaru, 13/12/2014).

Di zaman sekarang era milenial, sumber informasi buku akan digunakan oleh seseorang ketika mereka mendapatkan tugas. Fenomena seperti ini juga sering terjadi pada mahasiswa, di mana mereka akan mencari buku ketika mendapatkan tuntutan dari dosennya. Di lingkup perguruan tinggi, seorang mahasiswa sering melakukan hal-hal yang instan dalam aktivitasnya. Seperti halnya tindakan menyalin suatu tulisan dari karya orang lain tanpa mengikuti kaidah-kaidah yaitu tanpa mencantumkan nama sumbernya dalam penulisan karya.

Internet datang dengan menyediakan solusi atas kebutuhan informasi mahasiwa dengan kemudahan akses dibanding dengan penelusuran informasi dengan buku. Namun keberadaan internet juga memberikan dampak negatif untuk kehidupan manusia diantaranya: munculnya kemerosotan moral, perubahan nilai dan tindakan kriminal (Mansur, Isna; 2001). Kegiatan membaca dan menulis pada tingkat perguruan tinggi adalah aktivitas atau kegiatan yang sangat perlu dikembangkan dalam kehidupan mahasiswa.

Mahasiswa lebih memposisikan dirinya sebagai pengguna atau pemanfaat dari tulisan-tulisan orang lain bukan sebagai penggagas ide-ide untuk perkembangan ilmu pengetahuan. Padahal dengan melakukan kegiatan membaca buku literatur dapat memberikan lebih banyak informasi yang dibutuhkan dalam baik itu dalam penelitian yang akan memperkuat informasi hasil dari analisis maupun hipotesa ataupun memunculkan ide-ide kreatif. Perkembangan zaman yang semakin pesat, serta teknologi yang semakin canggih juga memberikan dampak yang besar bagi seluruh bidang seperti halnya dengan pendidikan (Bachtiar, Anwar; 1999).

Menurut Bukhori (2005) perkembangan teknologi informasi juga menghambat terbentuknya masyarakar literat dikalangan intelektual. Dikarenakan masyarakat Indonesia berawal dengan bertradisi lisan atau dikenal dalam istilah lain adalah oral society yang kemudian secara langsung bergerak mengalami kemajuan masuk pada budaya teknologi dimana mulai dikenal dengan media elektronik seperti yang awal kita kenal adalah TV dan radio. Masyarakat Indonesia telah langsung mengalami pelompatan tradisi dimana yang sebelumnya hanya mengenal tradisi mendongeng kemudian mengalami kemajuan masuk pada tradisi menonton padahal sebelumnya belum terbiasa dengan tradisi membaca. Masyarakat kita tidak siap mental untuk menghadapi tuntutan zaman (Sidik, Umar dalam Zain Labibah: 2011).

Mahasiswa harus dapat menyelesaikan kewajibannya yaitu melaksanakan seluruh aktivitas akademik sebagai peserta didik. Untuk mendukung penulisan dan penelitiannya, mahasiswa memerlukan sejumlah informasi ataupun dokumen literatur (Sujana, Janti, dkk ; 2013). Salah satu bentuk sumber informasi dan referensi yang bisa digunakan oleh mahasiswa dalam menunjang seluruh aktivitas akademiknya adalah dengan memanfaatkan buku. Di Era Generasi Milenial yang dipenuhi dengan perkembangan teknologi informasi dan komunikasi saat ini buku tidak lagi tersedia dalam bentuk tercetak saja namun kini buku juga tersedia dalam bentuk yang lebih modern yaitu elektronik atau lebih sering disebut dengan e-book. Seperti yang diucap Richard Whitlock seorang pencinta buku abad XVII (Purwono dalam Lasa Hs: 2008) "buku adalah penasehat yang bebas biaya, buku tidak menolak permintaan nasehat, buku adalah permata, buku adalah sahabat yang baik". 
Dari ungkapan ini bisa dipahami betapa berharganya buku sebagai salah satu penyimpan informasi. Buku juga merupakan kunci untuk memajukan kehidupan suatu bangsa. buku juga memiliki beberapa aspek penting di dalamnya yaitu: aspek karya, aspek informasi dan aspek pengetahuan (Suwarno, Wiji: 2011). Fungsi buku dalam dunia pendidikan tidak diragukan lagi. Fungsi buku telah dibuktikan dari sejak jaman dahulu dimana buku memiliki peranan yang sangat efektif untuk digunakan sebagai sarana pendidikan dan pranata ilmu pengetahuan. Keberadaan teknologi dan internet, sedikitnya jumlah terbitan buku setiap tahunnya tidak pernah mempengaruhi eksistensi buku dalam dunia Pendidikan.

\section{TINJAUAN PUSTAKA}

Penelitian tentang pemanfaatan buku telah dilakukan sebelumnya oleh beberapa peneliti. Hasil penelian dari setiap peneliti memiliki foKus yang tidak sama antara satu dengan lainnya. Ada beberapa penelitian tentang pemanfaatan buku diantaranya sebagai berikut:

Fahdli Aulia Ilham (2013) melakukan penelitian yang serupa yaitu dengan judul "Pemanfaatan Literatur Dalam Menunjang Prestasi Belajar Siswa Kelas XI IPS SMA Negeri 6 Padang”. Hasil pembahasannya menyatakan bahwa ada berbagai cara yang dilakukan siswa dalam memanfaatkan literatur yaitu dengan cara membaca dan memahami isi buku. Penelitian selanjutnya juga dilakukan oleh Ika Sukmawati yaitu "Pemanfaatan Buku Teks Pelajaran Pada Perpustakaan MAN 3 Yogyakarta sebagai sumber belajar siswa kelas XI Tahun Ajaran 2008/2009”. Pada kegiatan penelitian yang dilakukan menitik beratkan pada kebutuhan siswa, motif siswa, dan juga minat siswa dalam menggunakan buku teks pelajaran, selain itu kelengkapan koleksi buku, dan juga ketrampilan pustakawan serta kelengkapan fasilitas pada perpustakaan.

Penelitian tentang pemanfaatan buku juga dilakukan oleh Darwati, pada tahun 2010 dengan tesisnya yang berjudul "Pemanfaatan Buku Teks Oleh Guru dalam Pembelajaran Sejarah (Studi Kasus di SMA Negeri Kabupaten Semarang)”. Tujuan dari penelian ini adalah untuk mendapatkan informasi tentang (1) pemaknaan buku teks oleh guru (2) kriteria pemilihan buku teks bagi guru (3) tata cara pemanfaatan buku teks oleh guru pada proses kegiatan pembelajaran (4) kendala-kendala yang dihadapi guru dalam memanfaatkan buku teks pada pembelajaran sejarah. Hasil penelitian tentang pemanfaatan buku teks menunjukkan bahwa (1) buku teks dapat berfungsi yang sangat banyak dalam pembelajaran (2) kriteria pemilihan buku teks didasarkan pada relevansi materi (3) terdapat dua jenis pemanfaatan buku teks (4) kendala dalam memanfaatan buku teks.

Buku merupakan kumpulan tulisan atau gambar yang tersedia dalam bentuk buku tercetak disebut dengan buku teks dan buku tidak tercetak dikenal dengan istilah e-book yang mana di dalam kedua bentuk tersebut sama-sama mengandung ilmu pengetahuan. Menurut New Columbia Encyclopedia 1975, hal. 331 (dalam Puwono: 2009) mendefinikan buku adalah suatu karya tulis yang tersedia baik dalam bentuk naskah ataupun dalam bentuk cetakan yang cukup tebal dan panjang. Buku juga bisa dijadikan sebagai alat berkomunikasi. Buku memiliki berbagai macam fungsi seperti yang diungkapkan Puwono (2009) fungsi buku bagi kehidupan manusia atau sesuatu bangsa menjadi penting sekali akibat adanya perkembangan ilmu pengetahuan dan teknologi modern.

Buku memberikan pendidikan seumur hidup bagi umat manusia. Pada saat ini buku juga sudah menunjukkan fungsin yang sangat efektif sebagai penunjang dalam sarana pendidikan dan perkembangan ilmu pengetahuan. Ketika mendengar istilah buku orang cenderung mengarah 
kepada bentuk fisik sebuah buku. Namun seiring dengan melajunya ilmu pengetahuan dan teknologi, buku juga melakukan transformasi untuk mengikuti perkembangan jaman. Seperti yang diungkapkan oleh Suwarno (2011) berkat peran komputer dan teknologi informasi lainnya, sekarang ini buku tidak lagi sekedar diterbitkan berbentuk tercetak, tetapi buku juga terbit dalam bentuk e-book (elektronik book).

\section{METODE PENELITIAN}

Metode penelitian kualitatif deskriptif dan studi literatur digunakan dalam penelitian ini. Pendekatan kualitatif ini digunakan bukan semata-mata hanya mencari kebenaran, melainkan juga untuk mengetahui pemahaman subyek terhadap dunianya. Menurut Bogdan dan Taylor (dalam Moleong; 2004) mendifisikan pendekatan kualitatif sebagai prosedur penelitian untuk menghasilkan data deskriptif yaitu berupa kata-kata tertulis ataupun lisan dari orang-orang (informan) dan perilaku yang diamati. Dengan menggunakan metode kualitatif hasil penelitian ini dapat menginterpretasikan data yang diperoleh peneliti dari lapangan.

Metode penelitian yang digunakan dalam penelitian ini adalah metode deskriptif. Metode deskriptif adalah prosedur pemecahan masalah yang diselidiki dengan menggambarkan keadaan subjek/objek penelitian (Nawawi; 1993). Melalui pendekatan ini diharapkan mampu memberikan jawaban lebih dalam yang menyeluruh, bukan hanya bersifat permukaan dan pembuktian teori semata, sesuai dengan tujuan penelitian yang ingin dicapai. Penelitian ini menggambarkan keadaan yang nyata di lokasi penelitian tentang latar belakang tindakan mahasiswa dalam memilih memanfaatkan buku sebagai sumber bacaan utama untuk menunjang penulisan tugas akhir, dan hal-hal yang menjadi pertimbangan-pertimbangan mahasiswa dalam memanfaatkan buku untuk menunjang aktivitas akademiknya. Penelitian ini juga berupaya mendiskripsikan motivasi mahasiswa memanfaatkan buku sebagai sumber bacaan utama.

\section{HASIL DAN PEMBAHASAN}

\section{A. PILIHAN MEMANFAATKAN BUKU UNTUK MENUNJANG PENULISAN TESIS}

Pemanfaatan buku untuk menunjang aktivitas akademik merupakan hal yang biasa. Namun di era generasi milenial dengan adanya teknologi informasi yang terus berkembang sampai saat ini membuat mahasiswa menjadi terlena pada situasi yang serba dengan kemudahan/instan. Terdapat suatu pemikiran dan pertimbangan yang dilakukan mahasiswa sebelum mereka memilih untuk memanfaatkan buku dalam menunjang aktivitas akademiknya. Bagi masyarakat intelektual, informasi menjadi kebutuhan yang dominan untuk berlangsungnya kegiatan akademik. Mahasiswa membutuhkan informasi untuk menunjang tugas-tugas akademiknya. Informasi juga dibutuhkan oleh mahasiswa untuk menunjang penulitas tesis ataupun tugas akhirnya.

Setiap mahasiswa memiliki caranya masing-masing dalam memanfaatkan sumber informasi yang tersedia saat ini. Semua itu sah-sah saja karena setiap individu selalu dibekali dengan kemampuan untuk memilih dan atas hal tersebut individu dihadapkan pada berbagai macam pilihan sumber informasi. Orientasi pilihan rasional Coleman bahwa seseorang akan melakukan tindakan secara sengaja untuk mencapai sebuah tujuan, dimana tujuan itu akan dibangun oleh preferensi-prefensi (Ritzer \& Goodman: 2009). Dengan adanya pertimbangan-pertimbangan itu, akhirnya mengetahui apa yang dianggapnya memiliki keuntungan untuk tercapainya tujuan dari mahasiswa. Pada konteks ini sumber informasi buku menjadi sumber daya yang menjembatani mahasiswa dalam mencapai tujuan. 
Pemilihan sumber informasi yang digunakan oleh mahasiswa untuk menunjang aktivitas akademik disesuaikan dengan kebutuhan dari mahasiswa dan juga pemilihan literatur juga didasarkan pada jenis kegiatan yang dilakukannya. Situasi yang saat ini semuanya telah berbasis teknologi hal itu menjadi salah satu pertimbangan mahasiswa dalam memperoleh informasi. Pemaksimalan fungsi teknologi menjadi bagian yang dilakukan oleh mahasiswa di era yang semakin canggih ini. Internet memiliki peranan penting sebagai sarana atau media untuk memperoleh buku-buku yang kemudian dimanfaatakan untuk menunjang penulisan tesis. Selain pemanfaatan internet yang tersedia di era modern saat ini mahasiswa juga melakukan pertukaran sumber informasi.

Buku menjadi sumber informasi utama mahasiswa yang dapat memperdalam isi dari sebuah tulisan atau karya ilmiah mereka. Mahasiswa menganggap bahwa pemanfaatan buku sangatlah berpengaruh kepada kualitas tulisan atau karya yang dihasilkan. Seperti yang diungkapkan Suwarno (2011) bahwa buku memiliki berbagai aspek yang terkandung didalamnya, buku memiliki aspek karya, aspek informasi dan juga aspek pengetahuan. Pemanfaatan buku untuk menunjang aktivitas akademik ini merupakan sebagai upaya tindakan dari mahasiswa agar informasi yang mereka peroleh mempunyai landasan atau kekuatan ilmiah. Buku dianggap sebagai sumber informasi yang memiliki sifat keakuratan tinggi dan dapat dipertanggung jawabkan.

\section{B. PERAN PERPUSTAKAAN SEBAGAI PENYEDIA SUMBER INFORMASI}

Perpustakaan memiliki tugas penting untuk penyebaran informasi, jasa rujukan dan penelusuran literatur. Ketika dihadapkan pada kenyataan yang ada saat ini tujuan dan fungsi perpustakaan yang sebenarnya hanyalah menjadi sebuah wacana semata. Apalagi dengan saat ini adanya strereotip dan pencitraan yang beredar dikalangan pengguna. Perpustakaan hanyalah sebuah intitusi pelengkap yang ada di sebuah instansi. Persediaan buku yang ada pun sangat minim dan bahkan tidak memenuhi kebutuhan penggunanya. Apalagi di perpustakaan perguruan tinggi yang penggunanya merupakan mahasiswa sangat banyak membutuhkan referensi untuk menunjang tugas-tugas maupun tugas akhir, banyak kekecewaan yang dialami mahasiswa ketika berbicara tentang perpustakaan.

Saat ini mahasiswa lebih memilih memanfaatkan toko-toko buku untuk menggantikan peran perpustakaan. Selain itu lagi-lagi dengan memaksimalkan media internet untuk menelusur bukubuku yang bisa didapatkan dengan kemudahan akses dan murah. Perpustakaan perguruan tinggi pada saat ini sedang menghadapi puncak tantangannya sejak muncul banyaknya perpustakaan yang berbasis virtual telah menghadirkan berbagai macam sumber informasi yang dikemas dalam bentuk digital seperti e-book.

\section{PERAN DOSEN PEMBIMBING DALAM MEMANFAATKAN BUKU}

Dosen memberikan memiliki peranan yang penting dalam pemanfaatan buku kepada mahasiswanya. Saran dari para dosen menjadi salah satu bagian alasan mengapa mahasiswa memanfaatkan buku sebagai sumber referensi. Dosen yang memiliki kredibilitas lebih tinggi dibandingkan mahasiswa, menganggap buku memiliki tingkat akurasi lebih tinggi dibandingkan sumber informasi seperti yang ada di Google. Buku menjadi hal yang harus ada ketika mahasiswa mengerjakan karya tulis apapun sebagai aktivitas akademiknya karena buku ini memberikan legalitas kepada tulisan yang kita tuangkan dalam sebuah karya ilmiah.

\section{MOTIVASI MAHASISWA MEMANFAATKAN BUKU}

Bentuk tindakan rasional individu juga selalu terkait dengan kebutuhan mendasar individu tersebut. Setiap bertindak seseorang akan dipengaruhi oleh sebuah motivasi. Sedangkan maksud 
dari motivasi itu sendiri adalah suatu bentuk dorongan dalam diri seseorang agar dapat melakukan sesuatu hal atau tidakan. Dorongan yang dimaksud dalam motivasi itu juga yang menjadi sebuah sumber tenaga seseorang untuk mengerjakan suatu tindakan agar dapat tercapai suatu tujuan yang diinginkan. Motivasi akan menciptakan suatu tindakan yang diarahkan kepada tujuan untuk mencapai kepuasan. Seperti yang diungkapkan Ghufron dan Risnawita (2014) bahwa motivasi adalah keadaan yang ada dalam diri pribadi seseorang yang dapat mendorong keinginan seorang individu untuk dapat melakukan kegiatan-kegiatan tertentu guna mencapai tujuannya.

Mahasiswa memiliki dorongan yang menyebabkan mereka memanfaatkan buku untuk menunjang aktivitas akademiknya. Dalam pemanfaatan buku untuk menunjangaktivitas akademik mahasiswa memiliki motif-motif tertentu dalam melakukan tindakan tersebut yaitu 1) kebutuhan berprestasi mahasiswa akan berpengaruh terhadap tindakan yang akan dilakukan oleh mahasiswa untuk mencapai tujuan dari sebuah prestasi. Mahasiswa akan berusaha untuk menyelesaikan tugasnya sampai tugasnya tersebut benar-benar selesai; 2) sebagai seorang mahasiswa, yang merupakan agen perubahan, idealis adalah konsep pemikiran yang baik, karena seseorang yang idealis cenderung tidak mudah terbawa arus lingkungan, memiliki pendirian yang kuat, dan cenderung berani melakukan perubahan.

Orang-orang yang memiliki pola pikir idealis sudah terbukti dapat membuat perubahan dan mampu menciptakan berbagai inovasi. Di tengah persaingan dunia saat ini setiap individu khususnya mahasiswa yang merupakan penggiat akademisi harus mampu menunjukkan kelebihan dirinya. Mahasiswa dituntut untuk terus berkarya mengembangkan ilmu pengetahuan. Usaha yang dilakukan mahasiswa untuk menghasilkan sebuah karya yang bagus salah satunya adalah dengan memanfaatkan buku untuk menunjang aktivitas akademiknya; 3) lingkungan akademik memiliki peranan penting dalam mendukung seorang mahasiswa untuk melakukan kegiatan yang optimal untuk prestasi akademiknya.

\section{E. KEPUASAN MAHASISWA DALAM MEMANFAATKAN BUKU}

Buku seperti yang telah dijelaskan sebelumnya memiliki banyak manfaat untuk setiap manusia khususnya mahasiswa. Buku adalah jendela ilmu pengetahuan. Seperti yang diungkapkan Buckingham (dalam Tarigan, 1986) buku merupakan sebuah sarana untuk media pembelajaran yang umum dipergunakan pada tingkat sekolah dasar sampai pada tingkat perguruan tinggi untuk menunjang suatu program pengajaran. Banyak hal yang bisa didapat dari buku dan banyak hal pula keuntungan yang diperoleh dari memanfaatkan buku dibandingkan sumber informasi lain. Buku memberikan banyak informasi yang bisa digunakan untuk menunjang aktivitas akademik. Membaca buku juga akan memberikan dampak yang bagus untuk mahasiswa.

Dengan memanfaatkan buku mahasiswa secara langsung maupun tidak mempengaruhi perilaku dan cara berpikir. Mahasiswa sebagai kaum intelektual dituntut untuk berpikir sistematis. Salah satu manfaat buku ini adalah mengajari mahasiswa untuk berfikir secara sistematis. Dengan memanfaatkan buku, maka ilmu pengetahuan akan bertambah dan meningkatkan perbendaharaan kata seseorang, selain itu juga dapat melatih imajinasi dan daya pikir seseorang sehingga terpenuhi kepuasan intelektual.

\section{F. KELEBIHAN DAN KEKURANGAN BUKU}

Banyak hal yang diperoleh dari memanfaatkan buku untuk menunjang aktivitas akademik. Buku memenuhi kebutuhan informasi mahasiswa untuk menunjang aktivitas akademik. Buku memberikan tambahan wawasan dan membuka cara berpikir mahasiswa yang kadang sempit. 
Buku juga merupakan sebuah sarana komunikasi mahasiswa. Buku memiliki manfaat yang sangat besar untuk menunjang aktivitas akademik. Buku menjadi sebuah pondasi dari sebuah karya ilmiah baik itu buku dalam bentuk tercetak maupun dalam bentuk non cetak (ebook).

Tidak hanya manfaat saja, buku juga memiliki kekurangan yang menjadi pertimbangan bagi mahasiswa ketika akan memilih menggunakan buku sebagai sumber informasi untuk menunjang aktivitas akademik. Selain buku memberikan informasi yang terstruktur dan rinci, kekurangan buku yang didapatkan adalah ketersediaan buku yang sampai saat ini masih tergolong minim juga keberadaan buku yang belum bisa mengimbangi perkembangan ilmu pengetahuan yang selalu bersifat up to date.

\section{KESIMPULAN}

Mahasiswa memanfaatkan buku sebagai sumber informasi utama untuk menunjang aktivitas akademik karena berbagai alasan. Mahasiswa memiliki tujuan dan keinginan untuk segera menyelesaikan seluruh tugas yang diterima, mahasiswa juga terus berupaya untuk mendapatkan hasil yang terbaik dalam menyelesaikan tugasnya. Mahasiswa memiliki kesadaran diri dalam pemanfaatan buku sebagai sumber informasi penunjang aktivitas akademiknya. Pemanfaatan buku untuk menunjang aktivitas akademik ini juga dikarenakan adanya dorongan atau pengaruh dari dosen yang memiliki peranan mengarahkan mahasiswa dalam mengerjakan kegiatan pembelajaran. Selain didasarkan pada pertimbangan-pertimbangan, manusia memiliki motivasi yang mendasari dalam setiap tindakan yang dilakukan. Motivasi tersebut berupa dorongan prestasi, dorongan untuk terus berkarya. Mahasiswa juga mendapatkan dukungan dari lingkungan akademiknya yang memotivasi mahasiswa untuk memanfaatkan buku dengan memberikan saransaran buku yang bisa dimanfaatkan. Meskipun mahasiswa sekarang lebih menyukai hal-hal yang praktis dan berbau instan yang merupakan pengaruh dari globalisasi, dalam menunjang seluruh aktivitas akademiknya mahasiswa tetap memanfaatkan buku tercetak maupun non cetak sebagai sumber informasi utama.

\section{DAFTAR PUSTAKA}

----. April 2014. Pola Penggunaan Sumber Informasi Di Perpustakaan Oleh Pemustaka. Majalah Visi Pustaka. Ed. Vol 16 No. 1- April 2014. Perpustakaan Nasional Republik Indonesia.

Anwar, Bachtiar. 1999. Belajar sendiri bahasa pemrograman VRML 1.0. Jakarta. Elex Media

Asnawi, S. 2002. Teori motivasi: dalam Pendekatan Psikologi Industri dan Organisasi. Jakarta. Studio Press.

Coleman, James. S. 2009. Dasar-Dasar Teori Sosial: Foundations of Social Theory. Bandung. Nusa Media.

Darwati. 2010. Pemanfaatan Buku Teks Oleh Guru dalam Pembelajaran Sejarah (Studi Kasus di SMA Negeri Kabupaten Semarang). Tesis: Program Pascasarjana Universitas Sebelas Maret.

Gage, N. L., \& Berliner, D.C. (1998). Educational Phychology (6th ed.). Boston. Houghton Mifflin.

Ghufron, M. Nur, \& Rini, Risnawati S.2014. Teori-Teori Psikologi. Yogyakarta. Ar- Ruzz Media. 
Hadi, Abdul. Juni 2010. Dinamika Penelitian Skripsi Mahasiswa IAIN Raden Fatah Palembang. Jurnal Conciencia Vol X No. 1.

Ilham, Fahdli Aulia \& Elva Rahma. 2013. Pemanfaatan Literatur Dalam Menunjang Prestasi Belajar Siswa Kelas XI IPS SMA Negeri 6 Padang. Jurnal Ilmu Informasi Perpustakaan dan Kearsipan. Vol, 2, No. 1 September 2013, Seri A.

Lasa, Hs, dkk.. 2008. Perpustakaan dan Kebangkitan Bangsa. Yogyakarta. LPPI.

Moleong, Lexy J.. 2004. Metodologi Penelitian Kualitatif. Bandung. Remaja Rosdakarya.

Mulyana, Deddy. 2004. Metode Penelitian Kualitatif. Bandung. Remaja Rosdakarya. Nawawi, Hadari. 1993. Metode Penelitian Sosial. Yogyakarta. Gajah Mada.

Patton, M.Q.. 2002.Qualitative Research \& Evaluation Methods (3rd ed.). Thousand Oaks, CA. Sage

Peraturan Pemerintah RI No. 30 tahun 1990 tentang Pendidikan Tinggi. Peraturan Pemerintah No 60 tahun 1999 tentang Pendidikan Tinggi.

Priyanto, Ida F. \& Sri P. Sedyaningsih. 2013. Buku Digital: Kajian Literatur Perkembangan dan Pengaruhnya Pada Perpustakaan. Yogyakarta. Jurusan Ilmu Perpustakaan dan Informasi UIN Sunan Kalijaga; FIHRIS Jurnal Ilmu Perpustakaan dan Informasi, Vol VIII Nomor 2 (Juli-Desember 2013).

Puwono. 2008. Pemaknaan Buku Bagi Masyarakat Pembelajar. Jakarta. Sagung Seto. Rahmiati. 2014. Problematika Mahasiswa Dalam Menulis Karya Ilmiah. Jurnal Al

Hikmah Vol XV Nomor 1.

Ritzer, George, \& Douglas J.Goodman. 2009. Teori Sosiologi: Dari Teori Sosiologi Klasik Sampai Perkembangan Mutakhir Teori Sosial Postmodern. Yogyakarta. Kreasi Wacana.

Robbins, S.P. 2001. Psikologi Organisasi (Edisi ke-8). Jakarta. Prenhallindo. Sobur, Alex. 2009 . Psikologi Umum. Bandung . Pustaka Setia Bandung.

Sugiyono. 2008. Metode Penelitian Kuantitatif, Kualitatif dan R \& D. Bandung. Alfabeta.

Sukmawati, Ika. 2009. Pemanfaatan Buku Teks Pelajaran Pada Perpustakaan MAN 3 Yogyakarta Sebagai Sumber Belajar Siswa Kelas XI Tahun Ajaran 2008/2009. Skripsi thesis: UIN Sunan Kalijaga Yogyakarta.

Suwarno, Wiji. 2011. Perpustakaan dan Buku: Wacana Penulisan dan Penerbitan. Yogyakarta. Ar-Ruzz Media.

Umam, Khaerul. 2010. Perilaku Organisasi. Bandung. Pustaka Setia. Walgito, Bimo. 2010. Pengantar Psikologi Umum. Yogyakarta: Andi.

Yusup, Pawit M. Dan Priyo Subekti. 2010. Teori dan Praktik Penelusuran Informasi (Information Retrieval). Jakarta. Kencana.

Zain, Labibah, dkk. 2011. The Key Word: Perpustakaan di Mata Masyarakat. Yogyakarta. Perpustakaan UIN Sunan Kalijaga. 